\title{
URGENSI PENERAPAN SISTEM CYBER NOTARY DITENGAH PANDEMI COVID 19
}

\author{
Tamara Dwi Rizki Amanda \\ Fakultas Hukum Universitas Pembangunan Nasional Veteran Jakarta \\ Jl. RS. Fatmawati Raya, Pd. Labu, Kec. Cilandak, Kota Depok, Jawa Barat 12450 \\ Email: amandatamara765@gmail.com \\ Wardani Rizkianti \\ Fakultas Hukum Universitas Pembangunan Nasional Veteran Jakarta \\ Jl. Raya Fatmawati, Pd. Labu, Kec. Cilandak, Kota Depok, Jawa Barat 12450 \\ Email: rizkianti88@gmail.com
}

\begin{abstract}
Indonesia has designated the Covid-19 pandemic as a disease that causes a public health emergency and the government has issued several regulations requiring people to work from home. This research covers two main problems First, how is the validity of notary deeds made by the cyber notary system? Second, what is the urgency of implementing a cyber notary system amid the Covid-19 pandemic? This writing uses normative juridical research. Notary deeds made by cyber notary have the power of proof as underhand deeds. The importance of implementing cyber notary amid a pandemic is strengthened one of which is the Minister of Health Regulation Number 9 of 2020 and Government Regulation Number 21 of 2020 which requires closing the office sector and working from home to break the line of the spread of the coronavirus in Indonesia.
\end{abstract}

Key words: Pandemic, Cyber Notary, Notarial Deed.

ABSTRAK
Indonesia telah menetapkan pandemi Coronavirus Disease 2019 (COVID19) sebagai penyakit yang menimbulkan keadaan darurat kesehatan masyarakat, pemerintah telah mengeluarkan beberapa peraturan yang mengharuskan masyarakat untuk bekerja dari rumah (work from home). Penelitian ini meliputi dua pokok permasalahan yaitu yang Pertama, bagaiman keabsahan akta notaris yang dibuat dengan system cyber notary? Kedua, bagaimana urgensi penerapan sistem cyber notary ditengah pandemi Coronavirus Disease 2019 (COVID-19)? Penulisan ini menggunakan penelitian yuridis normatif. Akta notaris yang dibuat dengan cyber notary memiliki kekuatan pembuktian sebagai akta dibawah tangan. Pentingnya penerapan cyber notary ditengah pandemi diperkuat salah satunya dengan adanya Peraturan Menteri Kesehatan Republik Indonesia Nomor 9 Tahun 2020 dan Peraturan Pemerintah Nomor 21 Tahun 2020 yang mengharuskan untuk menutup sektor perkantoran serta bekerja dari rumah guna memutus tali penyebaran Coronavirus Disease 2019 (COVID-19) di Indonesia.

Kata kunci : Pandemi, Cyber Notary, Akta Notaris.

\section{PENDAHULUAN}

Dunia saat ini sedang berjuang melawan sebuah virus yang menjangkit manusia dibelahan dunia yaitu Coronavirus Disease 2019 (COVID19), serta penyebaran penyakit ini sangat cepat yaitu dengan cara 
penularan dari manusia satu kemanusia yang lain bahkan Coronavirus Disease 2019 (COVID-19) ini dapat menyebabkan kematian bagi sebagain orang. Kota Wuhan merupakan kota yang pertama kali terjangkit Coronavirus Disease 2019 (COVID19), mulanya masyarakat di Wuhan mengalami gejala gangguan pernapasan.

Kemudian hari demi hari angka orang-orang yang terjangkit virus ini terus menaik, hal ini disebabkan karena penyebaran Coronavirus Disease 2019 (COVID-19) ini sangatlah mudah bahkan secara cepat virus ini menyebar keseluruh dunia termasuk Indonesia. ${ }^{1}$

Di Indonesia pada pertengahan bulan maret telah ditemukannya 3 orang yang terjangkit Coronavirus Disease 2019 (COVID-19), kemudian ditemukannya lagi kasus-kasus seperti ini yang tentunya telah menyebar ke berbagai daerah di Indonesia.

Pemerintah telah menyatakan bahwa pandemi Coronavirus Disease 2019 (COVID-19) ini merupakan penyakit yang meyebabkan kedaruratan terhadap kesehatan masyarakat, sehingga Pemerintah dalam hal ini bertindak cepat dan menetapkan pandemi Coronavirus Disease 2019 (COVID-19) ini merupakan bencana nasional.

Pemerintah pun memberikan arahan kepada setiap masyarakat untuk melakukan pyshical distancing dan menggunakan masker dalam melakukan segala aktivitas.

Pemerintah Indonesia salah satunya telah mengeluarkan Peraturan Pemerintah Nomor 21 Tahun 2020 Tentang Pembatasan Sosial Berskala Besar Dalam Rangka Percepatan Penanganan Coronavirus Disease 2019 (COVID-19), dan Peraturan Menteri Kesehatan Republik Indonesia Nomor 9 Tahun 2020 Tentang Pedoman Pembatasan Sosial Berskala Besar Dalam Rangka Percepatan Penanganan Coronavirus Disease 2019 (COVID19).

Dengan adanya pengaturan tersebut yang menetapkan kebijakan untuk melakukan pembatasan secara fisik dengan orang lain sehingga dapat mengendalikan penyebaran Coronavirus Disease 2019 (COVID19), hal ini tentunya untuk mengurangi resiko penularan melakui kontak fisik

Syafrida dan Ralang Hartati, (2020), Bersama Melawan Virus Covid 19 di Indonesia, Jurnal Sosial \& Budaya Syar-I, Vol. 7, No. (_ _ , Hlm. 3. 
dalam menjalankan suatu pekerjaannya. $^{2}$

Hal inipun berdampak kepada profesi-profesi dibidang hukum salah satunya adalah profesi Notaris, apabila dilihat dalam Undang Undang Nomor 2 Tahun 2014 tentang Perubahan atas Undang Undang Nomor 30 Tahun 2004 tentang Jabatan Notaris (untuk selanjutnya disebut dengan UUJN) pada Pasal 1 Ayat (1) "Notaris adalah pejabat umum yang berwenang dalam membuat akta otentik dan memiliki kewenangan lainnya sebagaimana dimaksud dalam undang-undang ini atau berdasarkan undang-undang lainnya."3

Perkembangan di dunia kenotariatan, dikenal dengan adanya sistem cyber notary. Sebuah sistem cyber notary ini digunakan untuk mempermudah notaris dalam menyelesaikan tugas-tugasnya untuk membantu masyarakat dalam hal pembuatan akta otentik seperti pembuatan suatu perjanjian atau penetapan para pihak yang dimasukan sebuah akta otentik itu harus dibuat kedalam sebuah akta yang dengan cara berhadapan secara

2 Putra PM Siregar \&Ajeng Hanifa Zahra "Bencana Nasional Penyebaran COVID-19 sebagai Alasan Force Majeure, Apakah Bisa?" (https://www.djkn.kemenkeu.go.id/artikel/baca/13037/Bencana-Nasional-Penyebaran-COVID19-sebagai-Alasan-Force-Majeure-Apakah-Bisa.html diakses pada tanggal 14 Oktober 2020, Pukul 12:56).

3 Habib Adjie, (2008), Hukum Notaris Indonesia, Bandung; Refika Aditama, Hlm. 31.

4 R. A. Emma Nurita, (2012), Cyber Notary Pemahaman Awal dalam Konsep Pemikiran, Bandung; Refika Aditama, Hlm. 53.

yang semakin maju setiap harinya. ${ }^{4}$

Pada awalnya sistem cyber notary ini bersumber dari negara common law, di Indonesia sendiri cyber notary pernah dibahas namun masih adanya kendala dalam pengaturan cyber notary sehingga hal ini menimbulkan ketidakpastian hukum dalam penerapannya di Indonesia.

Dilihat dalam Pasal 15 ayat (3) UUJN "kewenangan lain yang diatur dalam peraturan perundang-undangan" mengatur mengenai cyber notary atau pembuatan mensertifikasi yang dilakukan secara elektronik.

Sedangkan apabila dilihat dalam UUJN dalam pasal 1 angka 7 bahwasanya "Akta Notaris yang selanjutnya disebut Akta adalah akta autentik yang dibuat oleh atau di hadapan Notaris menurut bentuk dan tata cara yang ditetapkan dalam undangundang ini."

Hal inipun memberi arti bahwa

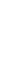


langsung antara notaris dan para pihak sedangkan dalam sistem cyber notary akta otentik itu tidak dibuat dengan berhadapan secara langsung karena dalam hal ini menggunakan media elektronik seperti video call.

Dalam membuat akta notaris apabila dilihat dalam UUJN pasal 16 ayat (1) huruf m menyatakan bahwa notaris dalam membacakan suatu akta otentik harus hadir dan harus disaksikan minimal 2 orang saksi serta setelah dibacakan harus ditandatangani oleh notaris, saksi, dan para pihak.

Sedangkan dalam menggunakan sistem cyber notary penghadap tidak langsung dihadapan notaris tetapi melalui alat elektronik seperti teleconference. Begitupun sebaliknya notaris tidak bisa membacakan akta otentik secara langsung didepan penghadap dan para saksi.

Konsep cyber notary di Indonesia telah disambut baik oleh UndangUndang Nomor 11 Tahun 2008 Tentang Informasi Transaksi Elektronik (untuk selanjutnya disebut UUITE) sebagaimana yang dimaksud dalam pasal 5 ayat (2) yang menyatakan "Informasi elektronik dan/atau dokumen elektronik dan/atau hasil cetakannya sebagaimana dimaksud pada ayat (1) merupakan perluasan dari alat bukti yang sah sesuai dengan Hukum Acara yang berlaku di Indonesia." dan Pasal 5 ayat (3) UUITE yang menyatakan "Informasi elektronik dan/atau dokumen elektronik dinyatakan sah apabila menggunakan sistem elektronik sesuai dengan ketentuan yang diatur dalam undangundang ini."

Apabila kita cermati dalam Pasal 5 ayat (4) UUITE yang menyatakan "Ketentuan mengenai informasi elektronik dan/atau dokumen elektronik sebagaimana dimaksud pada ayat (1) tidak berlaku untuk surat yang menurut undang-undang harus dibuat dalam bentuk tertulis; dan Surat beserta dokumennya yang menurut undangundang harus dibuat dalam bentuk akta notaris atau akta yang dibuat oleh pejabat pembuat akta."

Hal ini membuat penerapan cyber notary dalam hal pembuatan akta otentik dengan media elektronik masih sangat sulit untuk diterapkan di Indonesia karna tidak adanya kepastian hukum karena adanya konflik hukum yang ditentukan dalam UUJN dan UUITE.

Kemudian apabila dilihat dalam Kitab Hukum Perdata pada pasal 1868 
yang isinya menyatakan bahwa dalam pembuatan akta otentik itu sendiri harus dibuat secara langsung dengan cara berhadapan sesuai dengan tempat pejabat akta berada, sedangkan dalam situasi seperti ini dengan adanya pandemi Coronavirus Disease 2019 (COVID-19) tidak memungkinkan untuk membuat akta otentik dengan unsur berhadapan secara langsung. Sehingga dibutuhkan terobosan baru dalam hal pembuatan akta otentik yang memanfaatkan sistem cyber notary, karena sistem cyber notary pembuatan akta otentik dapat dilakukan secara virtual (videoconference). ${ }^{5}$

Adapun dalam peraturan yang mengatur tentang cyber notary masih terdapat tumpang tindih antara perundang-undangan yang satu (UUJN) dengan perundang-undangan yang lain (UUITE), apalagi dalam kondisi seperti ini ditengah pandemi Coronavirus Disease 2019 (COVID-19) sangat dibutuhkannya sistem cyber notary dalam membantu para notaris melakukan tugas-tugasnya serta dapat membantu para masayarakat apabila ingin melakukan pembuatan akta notaris dan hal-hal lainnya yang mengharuskan menggunakan jasa notaris sebagai pihak ke tiga.

Adapun rumusan masalah dalam penelitian ini yaitu, bagaimana keabsahan akta notaris yang dibuat dengan sistem cyber notary? dan bagaimana urgensi penerapan sistem cyber notary ditengah pandemi Coronavirus Disease 2019 (COVID19)?

Penelitian ini menggunakan penelitian yuridis normatif dengan menggunakan pendekatan perundangundangan (statute approach) dan pendekatan konseptual (conceptual approach) ${ }^{6}$

Penelitian ini menggunakan bahan hukum primer yang berupa suatu peraturan perundang-undangan yang telah terkait dengan isu penelitian dan bahan hukum sekunder yang dalam hal ini diperoleh dari berbagai sumber seperti buku, artikel, jurnal dan media pendukung mengenai materi dari penelitian ini. $^{7}$

5 R. Subekti dan R. Tjitrosudibio, (2009), Kitab Undang-undang Hukum Perdata, Jakarta; Pradnya Paramita, Hlm. 475.

6 Johnny Ibrahim, (2006), Teori dan Metodologi Penelitian Hukum Normatif, Malang; Bayumedia Publishing, Hlm. 28.

7 Dyah Ochtorina Susanti, dan A“an Efendi, (2014), Penelitian Hukum (Legal Research), Jakarta; Sinar Grafika, Hlm. 131. 
Pengumpulan bahan hukum kekuatan pembuktian lahiriah yaitu akta tersebut menggunakan studi kepustakaan dan menggunakan metode analisis data yaitu deskriptif analisis yaitu dengan cara menguraikan secara rinci dan sistematis atas permasalahan dan dianalisa berdasarkan teori-teori hukum sebagai suatu pisau bedah atas rangkaian dan peraturan yang mengenai pokok penelitian. ${ }^{8}$

\section{PEMBAHASAN}

Keabsahan Akta Notaris yang Dibuat

\section{Dengan Sistem Cyber Notary}

Indonesia telah menetapkan pengaturan mengenai alat bukti yang tertera dalam KUHPerdata pada pasal 1866 yang menyatakan "alat bukti terdiri dari bukti tulisan, bukti saksi, persangkaan, pengakuan dan sumpah". Selanjutnya pada KUHPerdata pasal 1876 mengatur tentang alat bukti tertulis yaitu akta dibuat oleh pejabat yang berwewenang selanjutnya disebut sebagai akta otentik dan akta dibawah tangan.

Pembuktian pada kedua akta tersebut berbeda, akta otentik kekuatan pembuktiannya sempurna karena didalam akta otentik terdapat unsur harus dianggap benar dan apabila ada seseorang yang tidak setuju akan isi dari akta tersebut maka harus bisa membuktikannya. serta dalam kekuatan pembuktian formil notaris dan para pihak memberikan pernyataan bahwa akta tersebut memang telah dibuat sebagaimana yang tertera dalam isi akta tersebut. ${ }^{9}$

$$
\text { Pasal } 1868 \quad \text { KUHPerdata }
$$

menyatakan "adanya tiga syarat akta otentik yaitu dibuat dan ditentukan oleh undang-undang, dibuat dihadapan pejabat yang berwewenang dan pejabat yang membuat akta tersebut harus mempunyai kewenangan terhadap akta tersebut yang akan di buat".

Melihat dari ketentuan pasal tersebut yang harus terpenuhi dalam membuat suatu akta otentik maka pembuatan akta otentik dengan menggunakan sistem cyber notary menjadi lebih sulit untuk diterapkan. Dalam pasal 1869 KUHPerdata menyatakan bahwa "apabila dalam suatu akta terdapat kecatatan maka akta tersebut menjadi akta dibawah tangan".

8 Peter Mahmud Marzuki, (2014), Penelitian Hukum, Edisi Revisi, Jakarta; Prenadamedia Group, Hlm. 64.

9 Dedy Pramono, (2015), Kekuatan Pembuktian Akta Yang Dibuat Oleh Notaris Selaku Pejabat Umum Menurut Hukum Acara Perdata Di Indonesia, Lex Jurnalica, Vol. 12, No. (__ ), Hlm. 4. 
UUJN telah mengatur mengenai kewenangan, kewajiban, dan larangan bagi seorang notaris dalam melakukan praktik kenotariatan. Hal ini bertujuan agar setiap notaris melakukan tugas dan kewajibannya seperti apa yang telah diamanatkan oleh undang-undang, pengertian tentang akta notaris pun telah diatur dalam pasal 1 angka 7 UUJN yang mengharuskan apabila ingin melakukan pembuatan akta harus dibuat secara langsung dihadapan notaris dan para penghadap serta mengenai cyber notary sendiri telah diatur dalam Pasal 15 ayat (3) UUJN. ${ }^{10}$

Tentunya dalam hal pembuatan akta otentik dengan menggunkan sistem cyber notary atau sistem berbasis elektronik dengan menggunakan media teleconfrance masih sulit diterapkan terlebih apabila kita melihat pengertian akta notaris yang diatur dalam UUJN. ${ }^{11}$

Dalam melakukan pembuatan akta otentik menggunakan sistem cyber notary apabila dilihat dalam Pasal 16 ayat (1) huruf c UUJN sangat bertentangan dengan kewajiban notaris itu sendiri serta pasal tersebut berbunyi "meletakan surat dan dokumen serta sidik jari penghadap pada minuta akta" hal ini jika dicerna lebih dalam mempunyai arti kehadiran seorang penghadap didepan notaris serta dengan melakukan peletakan sidik jari dalam membuat akta, akta tersebut mempunyai pembuktian sempurna atau sebagai akta otentik hal ini disebabkan karena setiap manusia mempunyai sidik jari yang berbeda-beda sedangkan dalam pembuatan akta otentik dengan cyber notary penghadap tidak bisa secara langsung meletakan sidik jarinya seperti yang telah diatur oleh pasal diatas.

Dalam Pasal 16 ayat (1) huruf m UUJN menyatakan untuk membacakan akta didepan penghadap, saksi serta notaris itu sendiri. Sedangkan akta otentik yang dibuat dengan sistem $c y b e r$ notary tidak menerapkannya unsur berhadapan secara langsung antara penghadap dan notaris itu sendiri tetapi menggunakan sebuah teknologi informasi seperti teleconferance begitupun sebaliknya notaris tidak bisa membacakan akta otentik secara langsung di depan penghadap maupun saksi.

10 Nawaaf Abdullah dan Munsyarif Abdul Chalim, (2017), Kedudukan Dan Kewenangan Notaris Dalam Membuat Akta Otentik, Jurnal Akta, Vol. 4, No. (__ ), Hlm. 6.

11 Syafiera Amelia and Aryani Witasari, (2019), Implementation of Notary Liability in The Making of Deed Based Act No. 2 of 2014 on Notary Position, Jurnal Acta, Vol. 6, No. 1, Hlm. 30. 
Pembuatan akta otentik dengan kerugian bagi para penghadap maupun sistem cyber notary yang diatur di notaris itu sendiri.

dalam UUJN pada Pasal 16 ayat (1) huruf $\mathrm{c}$ dan m masih terdapat hambatan dalam penerapan di Indonesia. Serta apabila dilihat dalam pasal 16 ayat (1) huruf m UUJN jika unsur-unsur tersebut tidak terpenuhi konsekuensi hukum terhadap akta tersebut menjadi akta yang memiliki pembuktian sebagai akta dibawah tangan, tidak lagi menjadi akta otentik hal ini sebagaimana diatur dalam pasal 16 ayat (9) UUJN.

Pasal 44 ayat (1) Undang-Undang Nomor 30 Tahun 2004 tentang Jabatan Notaris mengharuskan untuk melakukan penandatanganan setelah dibacakannya akta dihadapan para pihak, saksi, serta notaris itu sendiri.

Jika hal ini tidak bisa terpenuhi maka konsekuensi hukumnya akta notaris yang udah dibuat pembuktiannya menjadi akta dibawah tangan serta para penghadap dapat melakukan penuntutan, meminta ganti rugi dan juga bunga sebagai bentuk dari pertanggung-jawaban seorang notaris hal ini diatur dalam UUJN pada pasal 44 ayat (5). Dalam proses pembuatan akta dengan sistem cyber notary tentunya harus diperhatikan sehingga kedepannya tidak menimbulkan
Dalam pasal 5 ayat (4) UUITE telah menyatakan ketidak berlakuan terhadap surat yang harus di buat secara tertulis dan juga surat yang dibuat oleh pejabat yang berwenang. Maka dapat disimpulkan dalam membuat akta menggunakan sistem cyber notary berakibat hukum akta tersebut menjadi akta dibawah tangan berdasarkan pada penjelasan-penjelasan yang telah di uraikan oleh penulis

Apabila ingin menerapkan sistem cyber notary di Indonesia perlu adanya keselarasan hukum antara KUHPerdata, UUJN dan UUITE. Sehingga adanya keselarasan antara perundang-undangan satu dengan yang lain dalam mengatur mengenai pembuatan akta notaris dengan sistem cyber notary dapat melindungi semua pihak baik itu penghadap maupun notaris karena sudah adanya payung hukum yang jelas mengenai penerapan sistem cyber notary di Indonesia guna memudahkan baik bagi notaris maupun para penghadap yang ingin melakukan perbuatan hukum dengan menggunakan jasa notaris sebagai pihak ketiga.

\section{Urgensi Penerapan Sistem Cyber} Notary Ditengah Pandemi 
Coronavirus Disease 2019 (COVID19)

Terdapat sebuah perbedaan perkembangan dalam bidang kenotariatan dimana setiap negara tidak semuanya beraliran sama, maka dibagi menjadi aliran Civil Law dan aliran Common Law, berdasarkan aliran sistem hukum tersebut praktik notaris dibedakan lagi menjadi dua bagian yaitu Notaris Latin yang diterapkan dinegara yang menganut Civil Law sedangkan Notaris Anglo Saxon dianut oleh negara yang menganut aliran Common Law. ${ }^{12}$

Dalam prakteknya pada notaris yang menganut sistem Common Law notaris hanya melakukan pendaftaran surat-surat saja bahkan seorang notaris di negara tersebut tidak berperan secara langsung dalam menentukan dan membuat isi akta.

Berbeda dengan notaris dalam negara yang menganut sistem Civil Law dimana seorang notaris dapat memberikan nasihat secara langsung dan notaris dapat diminta pertanggung jawaban secara langsung terhadap ketetapan isi dalam akta.
Pembuktian akta yang dibuat oleh notaris menganut sistem Civil Law pembuktiannya sangat di perhitungkan di depan pengadilan berbeda halnya dengan akta yang dibuat oleh notaris di negara yang menganut sistem Common Law yang hanya bertanggung jawab atas akurasi dan legalitas isi perjanjian saja. $^{13}$

Indonesia merupakan negara yang termasuk dalam Eropa Continental dengan sistem Civil Law karena seperti yang kita ketahui Indonesia sendiri merupakan bekas jajahan Belanda, dimana hukum yang diterapkan di Indonesia banyak diadopsi dan bersumber dari hukum Belanda.

Saat ini Indonesia sedang menghadapi sebuah pandemi Coronavirus Disease 2019 (COVID19) dimana penyebaran virus ini semakin meningkat dan meluas diiringi dengan meningkatnya jumlah kasus orang-orang yang terjangkit serta angka kematian orang-orang yang terkena Coronavirus Disease 2019 (COVID19). Peningkatan jumlah tersebut sangat berdampak kepada aspek bernegara dan

12 Dwi Suryahartatia, (2018), Legal Education For Notary Position In Indonesia, Journal of Advances in Social Science and Humanities, Vol 4, No. (__ ), Hlm. 8.

13 Edmon Makarin, (2013), Notaris dan Transaksi Elektronik, Kajian Hukum tentang Cyber Notary atau Notaris Elektronik, Edisi ke-2, Jakarta; Rajawali Pers, Hlm. 133. 
juga mengganggu kesejahteraan tugas dari notaris itu sendiri terlebih masyarakat Indonesia. dalam masa pandemi Coronavirus

Tentunya dengan adanya pandemi Coronavirus Disease 2019 (COVIDDisease 2019 (COVID-19).

Cyber Notary dapat menjadi suatu 19) hal ini sangat berdampak setiap profesi tak terkecuali pada profesi notaris dimana para notaris harus menutup perkantoran dan melakukan pekerjaan dari rumah sehingga sangat bertentangan pada kewajiban notaris yang salah satunya mengharuskan untuk melakukan penyuluhan hukum terkait dengan pembuatan akta sebagaimana yang diatur dalam Pasal 15 ayat (2) UUJN.

Notaris mempunyai suatu kewajiban yang harus dijalankan untuk memberikan penyuluhan dan pelayanan kepada masyarakat seperti yang telah diamanatkan oleh UUJN tetapi dengan adanya pandemi Coronavirus Disease 2019 (COVID-19) membuat notaris pun sebagai warga negara Indonesia yang baik dituntut harus mematuhi peraturan yang sudah dibuat guna memutus penyebaran Coronavirus Disease 2019 (COVID-19) di Indonesia.

Sebagai jalan keluar terhadap permasalahan ini maka sudah saatnya sistem cyber notary diterapkan di Indonesia, karena sistem cyber notary lebih mempermudah kewenangan dan kebaharuan dalam dunia kenotariatan di Indoesia terlebih dalam keadaan pandemi Coronavirus Disease 2019 (COVID-19) yang berdampak pada tertundanya setiap perbuatan hukum dengan melibatkan pihak ketiga yakni notaris, pembaharuan tersebut diantaranya dalam pembuatan akta otentik berdasarkan pada UUJN dalam Pasal 1 angka (7) yang mengharuskan dibuat secara berhadapan langsung dengan notaris hal ini dengan adanya cyber notary unsur berhadapan tersebut dapat dilakukan dengan menggunakan media teleconference.

Dalam pasal 40 ayat (1) UUJN yang mengharuskan membacakan akta di depan saksi dan para pihak, hal ini dengan menggunakan sistem cyber notary maka pembacaan akta tersebut dapat dilakukan dengan menggunakan video call.

Pasal 44 ayat (1) UUJN yang mengatur mengenai penandatanganan secara langsung dalam pembuatan akta hal ini apabila menggunakan sistem cyber notary tanda tangan tersebut bisa dilakukan secara digital atau sidik jari 
secara digital sehingga mempermudah proses pembuatan akta yang dilakukan secara jarak jauh akibat dari adanya pandemi Coronavirus Disease 2019 (COVID-19) yang mengharuskan untuk melakukan pyshical distancing. ${ }^{14}$

Selain itu manfaat dari penerapan sistem cyber notary ialah dapat menjadi peluang dalam pelayanan jasa kenotariatan secara elekronik hal ini demi terwujudnya suatu pelayanan jasa yang cepat dan praktis sesuai dengan kemajuan teknologi serta cyber notary dapat membantu notaris dalam hal penyimpanan minuta akta yang dapat disimpan dengan menggunakan teknologi seperti USB flash disk, hard disk, google drive, server storage tentunya hal ini dapat memberikan rasa aman bagi para notaris yang harus menyimpan minuta akta dari setiap klien tanpa perlu harus merasa takut data-data tersebut akan rusak.

Dalam situasi pandemi Coronavirus Disease 2019 (COVID19) Pemerintah telah mengeluarkan peraturan diantaranya Peraturan Menteri Kesehatan Republik Indonesia serta mencegah penularan Coronavirus Nomor 9 Tahun 2020 Tentang Pedoman Pembatasan Sosial Berskala Besar
Dalam Rangka Percepatan Penanganan Corona Virus Disease 2019 (COVID19), Keputusan Presiden Nomor 11 Tahun 2020 Tentang Penetapan Kedaruratan Kesehatan Masyarakat Coronavirus Disease 2019 (COVID19), Peraturan Pemerintah Nomor 21 Tahun 2020 Tentang Pembatasan Sosial Berskala Besar Dalam Rangka Percepatan Penanganan Coronavirus Disease 2019 (COVID-19) dan Keputusan Gubernur Derah Khusus Ibukota Jakarta Nomor 1193 Tahun 2020 Tentang Perpanjang Pemberlakukan Pembatasan Sosial Berskala Besar Pada Masa Transisi Menuju Masyarakat Sehat, Aman dan Produktif.

Dalam peraturan diatas menyatakan Coronavirus Disease 2019 (COVIDberdampak besar terahadap kesehatan masyarakat sehingga masyarakat dihimbau untuk melakukan pekerjaan dari rumah serta melakukan social distancing atau physical distancing yang bertujuan memutus penyebaran virus ini 19) merupakan sebuah penyakit yang

14 Andi Suci Wahyuni, (2020), Urgensi Kebutuhan Akta Autentik Di Masa Pandemi Covid-19, Jurnal Hukum dan Dinamika Masyarakat, Vol 18, No. (__ (_), Hlm. 7. 
Disease 2019 (COVID-19) di sektor perkantoran. $^{15}$

Diterapkannya PSBB semakin memperkecil pergerakan masyarakat diluar rumah yang biasanya masyarakat melakukan banyak aktivitas diluar seperti sekolah, bekerja, beribadah dan berekreasi ketempat wisata sekarang sudah tidak bisa lagi dilakukan karena adanya pandemi Coronavirus Disease 2019 (COVID-19).

Adapun dampak dari pandemi juga merubah sistem dalam berinteraksi sosial yang ada dimasyarakat, dimana pada saat keadaan sebelum pandemi masyarakat berinteraksi secara langsung tetapi sekarang dengan adanya pandemi membuat interaksi antar masyarakat harus dilakukan melalui media teleconference begitu pula dalam melakukan pekerjaan dari rumah atau bekerja secara jarak jauh juga mengutamakan menggunakan kemajuan teknologi informasi seperti melalui media zoom meeting dan aplikasi sejenisnya.

Penerapan peraturan tersebut menjadi payung hukum yang harus di taati oleh setiap masyarakat guna menekan penurunan angka yang terjangkit Coronavirus Disease 2019 (COVID-19) di Indonesia, tentunya dampak pandemi ini juga sangat berpengaruh pada kestabilan ekonomi nasional sehingga dalam memberantas virus corona sangat diperlukannya tekat yang kuat antara pemerintah dan masyarakat guna memulihkan kesehatan masyarakat seperti sedia kala serta dapat membantu memulihkan kestabilan ekonomi di Indonesia.

Dalam keadaan darurat seperti ini memberikan arti bahwa keselamatan masyarakat merupakan hukum yang tertinggi dan harus di utamakan lebih dari apapun. ${ }^{16}$

Berdasarkan pada uraian-uraian yang telah dijabarkan oleh penulis terkait dengan cyber notary maka sudah seharusnya sistem tersebut dijalankan di negara ini serta apabila kita melihat peraturan-peraturan yang telah dibuat oleh Pemerintah yang mengharuskan kita sebagai warga masyarakat Indonesia yang baik harus taat dan patuh terhadap peraturan yang dibuat

15 Rezky Panji Perdana Martua Hasibuan dan Anisa Ashari, (2020), Optimasi Peran Negara Menghadapi Pandemi Corona Virus Disease 2019 dalam Perspektif Hukum Tata Negara Darurat, Jurnal Sosial \& Budaya Syar-I, Vol. 7, No. (__ ), Hlm. 8.

16 Ahmad Fauzi, (2020), Implementasi Pembatasan Sosial Berskala Besar Sebuah Kebijakan Publik Dalam Penanganan Pandemi Covid-19, Jurnal Ilmu Administrasi Negara, Vol. 16, No. (__), Hlm. 5. 
oleh pemerintah guna mengedepankan keselamatan semua manusia dan tentunya hal ini pun menjadi kunci bahwa memang sudah saatnya sistem cyber notary dalam bidang kenotariatan diterapkan di Indonesia sehingga dapat memudahkan pekerjaan notaris khususnya dalam keadaan pandemi seperti saat ini dan memudahkan para pihak yang ingin melakukan perbuatan hukum dengan melibatkan pihak ketiga yaitu jasa notaris tanpa khawatir akan tertular Coronavirus Disease 2019 (COVID-19).

\section{KESIMPULAN}

1. Dalam membuat akta dengan menggunakan cyber notary mempunyai pembuktian sebagai akta dibawah tangan bukan lagi sebagai akta otentik karena belum adanya kepastian hukum serta adanya tumpang tindih dan pertentangan antara KUHPerdata, UUJN, dan UUITE.

Sistem cyber notary telah diatur dalam Pasal 15 ayat (3) UUJN tetapi dalam pembuatan akta notaris sebagaimana diatur dalam Pasal 1868 KUHPerdata menyatakan akta otentik di buat di hadapan pejabat dan pejabat tersebut harus mempunyai kewenangan terhadap akta tersebut yang akan di buat, hal ini membuat akta otentik dengan menggunakan cyber notary menjadi lebih sulit diterapkan.

Pasal 5 ayat (4) UUITE juga menyatakan ketidakberlakuan terhadap surat yang dibuat secara tertulis dan surat yang dibuat oleh pejawab yang berwenang. Selain itu jika salah satu unsur dalam UUJN tidak terpenuhi maka akta tersebut memiliki pembuktian sebagai akta dibawah tangan.

2. Indonesia sedang dilanda sebuah pandemi Coronavirus Disease 2019 (COVID-19) yang semakin meningkat dan meluas diiringi dengan meningkatnya jumlah kasus orang-orang yang terjangkit serta angka kematian orang-orang yang terkena Coronavirus Disease 2019 (COVID-19), tentunya hal ini berdampak pada profesi notaris dimana para notaris harus menutup perkantoran dan melakukan pekerjaan dari rumah sehingga sangat bertentangan pada kewajiban notaris yang salah satunya mengharuskan untuk memberikan pengetahuan hukum yang berkaitan dengan tugas dan kewenangan dari notaris. Maka sebagai jalan keluar terhadap 
permasalahan ini maka sudah saatnya sistem cyber notary diterapkan di Indonesia, sistem cyber notary sendiri memberikan kemudahan bagi notaris dan penghadap dalam melakukan perbuatan hukum secara jarak jauh terlebih saat pandemi Coronavirus Disease 2019 (COVID19) masyarakat diharuskan untuk menerapkan social distancing. Pemerintah juga telah mengeluarkan peraturan terkait dengan penanganan Coronavirus Disease 2019 (COVID19) guna menghimbau untuk setiap masyarakat menaati peraturan tersebut guna memperlambat penyebaran Coronavirus Disease 2019 (COVID-19) serta menjadi kunci bahwa memang sudah saatnya sistem cyber notary dalam bidang kenotariatan diterapkan di Indonesia.

\section{SARAN}

1. Dalam menciptakan suatu kepastian hukum maka perlu adanya keselarasan hukum antara KUHPerdata, UUJN, dan UUITE. Sehingga dengan adanya keselarasan antara Perundang-Undangan satu dengan yang lain dalam mengatur mengenai perbuatan hukum pembuatan akta otentik dengan sistem cyber notary dapat melindungi notaris dan para penghadap hal ini dikarenakan sudah adanya payung hukum yang jelas.

2. Sudah seharusnya cyber notary diterapkan di Indonesia, mengingat pemerintah telah mengambil langkah cepat dengan mengeluarkan beberapa peraturan terkait dengan Coronavirus Disease 2019 (COVID-19). Dimana dalam peraturan tersebut mengharuskan semua masyarakat untuk melakukan pekerjaan dari rumah, tentunya hal ini dapat menjadi langkah yang efektif dalam dunia kenotariatan yaitu dengan mempermudah pekerjaan dari notaris serta mempermudah masyarakat dalam melakukan perbuatan hukum dengan menggunakan jasa notaris yang dengan diterapkan cyber notary perbuatan hukum tersebut dapat dilakukan secara jarak jauh sehingga tidak perlu khawatir akan tertular Coronavirus Disease 2019 (COVID19).

\section{DAFTAR PUSTAKA}

\section{Peraturan Perundang-Undangan}

Kitab Undang-Undang Hukum Perdata.

Undang-Undang No 2 Tahun 2014 Tentang Perubahan Atas UndangUndang Nomor 30 Tahun 2004 Tentang Jabatan Notaris

Undang-Undang Nomor19 Tahun 2016 Tentang Perubahan Atas Undang- 
Undang Nomor 11 Tahun 2008 Tentang Informasi Dan Transaksi Elektronik.

Keputusan Presiden Nomor 11 Tahun 2020 Tentang Penetapan Kedaruratan Kesehatan Masyarakat Corona Virus Disease.

Peraturan Menteri Kesehatan Republik Indonesia Nomor 9 Tahun 2020 tentang Pedoman Pembatasan Sosial Berskala Besar Dalam Rangka Percepatan Penanganan Corona Virus Disease 2019 (COVID-19).

Peraturan Pemerintah Nomor 21 Tahun 2020 tentang Pembatasan Sosial Berskala Besar Dalam Rangka Percepatan Penanganan Corona Virus Disease 2019 (COVID-19).

Keputusan Gubernur Derah Khusus Ibukota Jakarta Nomor 1193 Tahun 2020 Tentang Perpanjang Pemberlakukan Pembatasan Sosial Berskala Besar Pada Masa Transisi Menuju Masyarakat Sehat, Aman dan Produktif.

\section{Buku}

Dyah Ochtorina Susanti dan $\mathrm{A}^{\text {eean }}$ Efendi, (2014), Penelitian Hukum (Legal Research), Jakarta; Sinar Grafika.

Edmon Makarin, (2013), Notaris dan Transaksi Elektronik, Kajian Hukum tentang Cyber Notary atau Notaris Elektronik, Edisi ke-2, Jakarta; Rajawali Pers.

Habib Adjie, (2008), Hukum Notaris Indonesia, Bandung; Refika Aditama.

Johnny Ibrahim, (2006), Teori dan Metodologi Penelitian Hukum Normatif, Malang; Bayumedia Publishing.
Nurita, R. A. Emma, (2012), Cyber Notary Pemahaman Awal dalam Konsep Pemikiran, Bandung; Refika Aditama.

Peter Mahmud Marzuki, (2014), Penelitian Hukum, Edisi Revisi, Jakarta; Prenadamedia Group.

Subekti dan R. Tjitrosudibio, (2009), Kitab Undang-undang Hukum Perdata, Jakarta; Pradnya Paramita.

\section{Jurnal}

Ahmad Fauzi, (2020), Implementasi Pembatasan Sosial Berskala Besar Sebuah Kebijakan Publik Dalam Penanganan Pandemi Covid-19, Jurnal Ilmu Administrasi Negara, Vol. 16, No.

Andi Suci Wahyuni, (2020), Urgensi Kebutuhan Akta Autentik Di Masa Pandemi Covid-19, Jurnal Hukum dan Dinamika Masyarakat, Vol. 18, No. (

Dedy Pramo, (2015), Kekuatan Pembuktian Akta Yang Dibuat Oleh Notaris Selaku Pejabat Umum Menurut Hukum Acara Perdata Di Indonesia, Lex Jurnalica, Vol. 12, No. (__ $)$.

Dwi Suryahartatia, (2018), Legal Education For Notary Position In Indonesia, Journal of Advances in Social Science and Humanities, Vol 4, No. (__ ).

Hasibuan, Rezky Panji Perdana Martua dan Anisa Ashari, (2020), Optimasi Peran Negara Menghadapi Pandemi Corona Virus Disease 2019 dalam Perspektif Hukum Tata Negara Darurat, Jurnal Sosial \& Budaya Syar-I, Vol 7, No. (__ ).

Nawaaf Abdullah dan Munsyarif Abdul Chalim, (2017), Kedudukan Dan Kewenangan Notaris Dalam 
Membuat Akta Otentik, Jurnal Akta, Vol. 4, No.

Syafiera Amelia dan Aryani Witasari, (2019), Implementation of Notary Liability in The Making of Deed Based Act No. 2 of 2014 on Notary Position, Jurnal Acta, 2019, Vol. 6, No. 1.

Syafrida dan Ralang Hartati, (2020), Bersama Melawan Virus Covid 19 di Indonesia, Jurnal Sosial \& Budaya Syar-I, Vol. 7, No.

\section{Internet}

Siregar, Putra PM, Ajeng Hanifa Zahra. (14 April 2020), Bencana Nasional Penyebaran COVID-19 sebagai Alasan Force Majeure, Apakah Bisa?, https://www.djkn.kemenkeu.go.id/ artikel/baca/13037/BencanaNasional-Penyebaran-COVID-19sebagai-Alasan-Force-MajeureApakah-Bisa.html (diakses pada tanggal 14 Oktober 2020, Pukul $12: 56)$ 